\title{
Beijing Subway and the Political and Economic Development of China
}

\author{
Yixiao Guo \\ ${ }^{1}$ The Hotchkiss School, Lakeville, USA \\ Correspondence: Yixiao Guo, The Hotchkiss School, Lakeville, CT, USA. E-mail: yguo@hotchkiss.org
}

Received: November 12, 2018 Accepted: February 2, 2019 Online Published: April 28, 2019

doi:10.5539/par.v8n1p23

URL: http://dx.doi.org/10.5539/par.v8n1p23

\begin{abstract}
This research paper analyses the main purposes the Beijing subway system, which served from 1969 to now as a tool of political defense as well as a transportation system. The notion to construct the system arose in 1953, but the first section of today's Line 1 did not open until September 1969. ${ }^{1}$ Today, the Beijing subway system is the world's busiest in terms of annual ridership and the world's second longest subway system, ranking only behind Shanghai's. (Xinhua News Agency, 2017, http://www.xinhuanet.com/politics/2017-12/30/c_1122188643.htm.) The political and economic development and trends in China in the second half of $20^{\text {th }}$ century and the first decade of the $21^{\text {st }}$ century, such as the Cultural Revolution and the 2008 Olympics, affected the subway system's development greatly. This paper examines Chinese documents with the aim of providing a general understanding of the development and purpose of the Beijing system, through political, economic and technical analysis, among others, of its history.
\end{abstract}

There exists almost no document, either in English or Chinese, that analyzes the development of Beijing's subway system. However, this topic should be considered important, as it provides an alternative way of viewing the development of China and its governing principles throughout its late- $20^{\text {th }}$ century and current-day history.

Keywords: Beijing subway, history of subway, Chinese politics, Chinese economy, Beijing history, modern Chinese history

\section{1953-1976: The Genesis Amongst Conflicts: All Hail Chairman Mao}

The genesis of the Beijing subway system was the result of Chinese political and militaristic motives. Stretching through the period directly after the Korean War (1950-1953) and the Cultural Revolution (1966-1976), political and national defense needs shaped the subway system's further development and functioning. (Millett, 2018, https://www.britannica.com/event/Korean-War; Lieberthal, 2018 , https://www.britannica.com/event/Cultural-Revolution.)

During the early planning stages of the Beijing subway system, national defense was cited as the primary purpose of its development. The first intention to build a subway under Beijing can be found in a document from September 1953, the Major Points on Plans for the Reconstruction and Expansion of Beijing. (Sun \& Xu, 2013, pp. 218) The document states that "to provide citizens with the most convenient and economic transportation tool, especially to fit needs in national defense, [the city] must plan the construction of the subway at its earliest convenience." (Z. Xie, Y. Xie, \& S. Zhang, Comps., 2011, pp. 8) However, in the early 1950s, the Chinese government had no experience with building a subway system, therefore resorted to Soviet experts for help. The Soviet experts thought that Beijing did not need its own subway system, as the construction would be overly expensive and civil transport needs could be managed by ground transportation alone. (Xie, 2011, pp. 8) The city officials of Beijing disagreed, however, sending a telegram on May 5, 1954 to the National Construction Committee urging for the construction of underground subway. The telegram states that "considering long-term national defense needs, especially considering national defense needs in the age of nuclear warfare, [Beijing] should consider constructing a subway." (Xie, 2011, pp. 8)

The timing of the introduction of the subway construction proposal also indicates defensive needs as the primary

\footnotetext{
${ }^{1}$ Line 1 referred to here is the combination of the western part (west of Nanlishilu) of Phase I of the project and the later constructed part, which ran service to Bawangfen (now Sihui East). The eastern part of Phase I (east of Nanlishilu) were combined with Phase II of the project to from the current inner loop line, line 2.
} 
reason for construction. The armistice for the Korean War was signed on July 27, 1953, and the subway proposal was brought about in September of that year. The timing is too perfect for the connections to be coincidental. The Korean War is recognized to have ended without a victory, as both sides neither gained much nor lost much land with the armistice, despite sacrificing many resources. (Kissinger, 2012, pp. 150) However, the war helped China "build up military credibility," as the People's Liberation Army was able to achieve a draw against the United States, a country that had considerable technological and economic advantage. (Kissinger, 2012, pp. 150; Farley, 2017 , https://nationalinterest.org/blog/the-buzz/china-vs-america-why-the-korean-war-was-total-hell-its-not-22196) With this new military confidence, as well as the end of a major conflict that exhausted resources on both sides, the Chinese government deemed a full-scale invasion on the Chinese mainland by foreign forces to be impossible.

The government thus created a period of stability in which the subway construction could begin and proceed. However, though a foreign invasion was thought to be impossible, the government did worry about the possibilities of an aerial attack: therefore, they determined the construction of the subway to be necessary, as the system could serve as a shelter and provide evacuation routes. (Xie, 2011, pp. 40) The documents and timing of the construction show that the original motive for the Beijing subway was rooted in a desire for better military defense: transportation was cited only as a potential benefit.

However, during the Sino-Soviet split of 1960, all Soviet engineers were ordered to leave China and took with them their engineering and design drafts for the Beijing subway. Along with economic crisis in China, the subway construction was placed on hold before physical construction could actually begin. (Kissinger, 2012, pp. 161; Xie, 2011, pp. 38) It took another period of destabilization around Chinese border to forced government officials to consider further the defense potential for the subway project, to receive funding, and to begin construction. Border disputes with India around the Himalayan region led to the Sino-Indian war in 1962, and the US became further involved in Vietnam after the Gulf of Tonkin resolution in 1964.

These border instabilities deeply worried the Chinese government. (Garver, http://indianstrategicknowledgeonline.com/web/china\%20decision\%20for\%201962\%20war\%202003.pdf.) On August 19, 1964, the deputy director of CCP's financial committee Li Fuchun, Deputy Director of State Council Bo Yibo, and Deputy Director of Defense department Luo Ruiqing proposed together to Mao Zedong that Beijing should reinstate plans to construct a subway system, in order to defend against an enemy attack. ${ }^{2}$ (Mingrenjianli, http://www.gerenjianli.com/Mingren/03/rtr9de1rle561rl.html; Chang, http://cpc.people.com.cn/BIG5/64093/64387/5309618.html;

Zhang, http://cpc.people.com.cn/GB/64162/126778/127855/7537195.html; Xie, 2011, pp.41) Mao accepted the proposal and the subsequent planning and construction, led by the State Railway Department, was included in China's third Five Year Plan. (Xie, 2011, pp. 41)

National defense needs, rather than requirements for effective transportation, casted a heavier influence on the Beijing subway's design. The original design concept featured tunnels that would be buried at least 70-80 meters underground. (Xie, 2011, pp. 33) In 1959, two vertical shafts were constructed in the Beijing neighborhoods of Muxidi and Gongzhufen, each with a depth of 120 meters for engineering and construction testing. (Xie, 2011, pp. 32) A report entitled Report Concerning Beijing Subway Project Phase One, which was signed off by Prime Minister Zhou Enlai, proposed both Phase One subway lines to be buried around 100 meters underground. (Xie, 2011, pp. 33) Intentions to build with such depth underground were eventually abandoned due to high construction costs and because China lacked the relevant construction technique. The depth of the station also meant it would take much longer for shelter seekers to gain access during an attack, and the slanted passageway that connected the station to ground exits and entrances could be extremely unstable during bombings. (Xie, 2011, pp. 34-35)

The Chinese government did not abandon their pursuit for defense, though, as the eventual construction of both lines utilized the "protected shallow depth" method, meaning that the subway would be buried around 20-30 meters underground, but with reinforced structures that could withstand "assorted attacks while within a reasonable construction cost." (Xie, 2011, pp. 43) The western end of Line 1, or phase I of the project, connects to the Jingmen Railroad, and was designed as an escape route out of Beijing in case of emergency. Throughout discussions about the subway's design and construction, defense and protection were always the primary concerns. Convenience and efficiency for daily commuters was not the major reason for adopting the "protected shallow depth" plan, it simply appeared as a positive consequence in comparison to the 100-meter plan. (Xie,

\footnotetext{
${ }^{2}$ The document was called in Report of How Can Construction of National Economy Defend Against Enemy Attack.
} 
2011, pp. 35)

The construction of the Beijing subway system also functioned as a political project. Much of the construction was done by the railroad military, a special type of army under the national government's direct control, whose funding was dedicated to the construction and operation of railroads. (Xie, 2011, pp. 61) When the subway construction neared its completion in mid-1969, the fourth year of the Cultural Revolution, the government required each station to emphasize Maoism. Statues of Mao Zedong were erected in stations, where his words and commands also hung. (Xie, 2011, pp. 90-91) Photos of Mao, poems by Mao, and his political instructions can also be found around the Beijing subway system. (Xie, 2011, pp. 90-91)

The workers serving the subway system also needed to prove a "clean" political background, meaning they had not defied the Communist Party's command in any ways. Due to the workers' poor education and general lack of experience and knowledge of running the subway system, major fires broke out in the tunnels on November 3 and 11, 1969, a mere month after the subway construction was officially completed. (Xie, 2011, pp. 96-97) The fires were examined carefully and reports were produced. When the Report Regarding Subway Car Fire that Caused Injury and Death was presented to Prime Minister Zhou Enlai on November 12, he wrote that "the subway [operating] organization has grave [political] impurity, along with technical faults. One must start politically, find the source of the problem through political criticism, personal changes and strict enforcement of the party rules. Only then can mistakes be corrected and [the system] reformed." (Xie, 2011, pp. 98) His instruction shows the major role that politics played in daily operations of the subway, as the fires were considered to be the result of political, rather than technical, mistakes. In 1970, operations of the subway were handed directly to the Railway Military's 12th division, signaling the greater role politics would play in the system. The national government and the army now directly spearheaded the construction and operation of the system. (Xie, 2011, pp. 103)

The subway system was reformed in pursuit for more efficient operation in October 1970, and the entire system's personnel were reorganized into units representing each station. The system also included a "political works division," which had three subdivisions: organization crew, propaganda crew, and political defense crew, in charge of rooting out those who had said or done things against the party. (Xie, 2011, pp. 109-111) The system also included a "reception crew," which took on political reception missions from the central government, the State Council and the military. (Xie, 2011, pp. 138) This division hosted visitors including Canadian Prime Minister Pierre Trudeau, Great Britain Prime Minister Edward Heath and many other international and regional leaders. (Xie, 2011, pp. 142) Visits from political leaders caused the suspension of regular subway service. (Xie, 2011, pp. 95) The existence of these organizations and groups, and the precedence they took over the everyday needs of Beijing's commuters, clearly showcases that the subway served as a political tool.

When operations to test the Beijing subway system began in January 1971, the general public could not easily gain access to the system. To purchase a ticket, a passenger had to have a recommendation letter from his or her employer. (Xie, 2011, pp. 121) Even when passenger demand grew, each one still needed a worker's or student's certificate to purchase a ticket. (Xie, 2011, pp. 122) Recommendation letters, in general, were only given to workers that performed well in jobs and were politically loyal to the party. Such policies are examples of the subway system's prioritizing politics over convenience for daily commuters as well as over intellectual freedom regarding Maoist ideology, and were not abandoned until March 1973 in response to continuous increase in demand. (Xie, 2011, pp. 122)

\section{1977-2001: "Are We Serving the Public?"}

With the Cultural Revolution reaching its end in the later months of 1976 following the death of Mao Zedong in September and the appointment of Hua Guofeng in August the following year, China adopted a much more open economic and political agenda under the leadership of Deng Xiaoping. Under him and subsequent leaders, China's GDP grew from $\$ 147.3$ billion in 1978 to $\$ 4.9$ trillion in 2009, marking one of the greatest economic booms in the history of the world. (Wearden, 2010, https://www.theguardian.com/business/2010/aug/16/chinese-economic-boom) During this transitional period in Chinese history, the subway system's focus shifted from serving political and militaristic needs to serving the transportation needs of the general public. The subway operators instilled a new operation philosophy based on efficiency and customers, and subway system implemented further constructions as it considered more diverse economic plans, such as loans from foreign governments. ${ }^{3}$

Shortly after the end of the Cultural Revolution, in 1977, the subway management office proposed New

\footnotetext{
${ }^{3}$ The subway system was no longer managed by national government as the system developed, although most of the system is still considered to be public property under national government's control.
} 
Operational Standards, which reported standards much more tailored to efficiently serving passengers. The Standards was 2,550 Chinese characters long, and only 106 of the characters, or about $4 \%$ of the entire length, described needs for national defense. In comparison to how the government stressed national defense during the design and construction phase of the subway system, $4 \%$ signals the company's new focus on daily operation and transportation. (Xie, 2011, pp. 176) The subway company also sent employees to Japan in the same year to observe how their subways are functioning, and were impressed by the Japanese 4S (Safety, Security, Speed, Service) operational goals. (Xie, 2011, pp. 176) This observation, along with other influences, led to the setting of the company's own operational focuses - Safety, Precision, Efficiency, Service - in 1978. (Xie, 2011, pp. 178)

Besides this shift in general operational philosophies, the company also implemented, in the years after the Cultural Revolution, new and more precise, operational guidelines. The service guideline proposed and adopted in 1977 promoted "hospitality and enthusiasm" along with other welcoming ways to treat commuters. (Xie, 2011, pp. 182) Different system-wide surveys found the existing technologies to be flawed and a maintenance and inspection standard to be lacking. In 1978-82, new standards and checks were therefore imposed on the maintenance and operation of electrical and communication systems. (Xie, 2011, pp. 198-199) A new responsibility-sharing system was also established inside the transportation company between 1977-78, as different sections and individual employees were assigned responsibility in taking care of their equipment and reporting faults. The higher-ups were also made responsible for the financial well-being of the company. (Xie, 2011, pp. 230-231)

The company also aimed to improve the reliability of the system through conducting surveys, adding more trains and scheduling the system more efficiently, all of which happened alongside technological advancements. Starting in 1977, operation hours were extended to $5 \mathrm{am}$ and $11 \mathrm{pm}$ from the previous $6 \mathrm{am}$ to $9 \mathrm{pm}$ schedule, and train intervals were reduced to 5 minutes from the original 8. (Xie, 2011, pp. 178) Line $1^{4}$ was running on 3-minute intervals by 1996 , and the on-time rate was up to $99.95 \%$ by 2000 . (Xie, 2011, pp. 353, 369) The company also began selling tickets and offered monthly passes for customers who commuted daily, a major shift from the previous recommendation letter system. (Xie, 2011, pp. 180)

In order to better measure passenger satisfaction on the subway system, the company also began to conduct surveys on its customers. In 1978, the company's first large-scale survey, which was open to all customers, managed to gather information on the average traveling distance and duration. (Xie, 2011, pp. 184) Along with yearly surveys conducted on randomly selected groups, these surveys helped the system deal with increasing customers as it began to carry the burden of daily commuting after the end of the Cultural Revolution. Computers even started to assisted in survey-conducting from 1983. (Xie, 2011, pp. 185) Through improvements in operation philosophies, a better understanding customers' needs and general facility update, the system's efficiency increased greatly. Line 1 carried 30 million customers in 1978, and by 1984, that number has risen to over 100 million. The system managed an impressive $98 \%$ on-time rate as well. (Xie, 2011, pp. 186)

Besides changes in philosophy and day-to-day operations, the company also restructured itself to fit the transportation and service needs instead of defense and political needs. To combat the lack of technical staff and prepare for the increase in ridership, in 1976 the company started training technician through its own schools, a practice that is continued today. (Xie, 2011, pp. 204) The company created different offices and departments to standardize and carry out maintenance and operational procedures in response to problems revealed during the system-wide inspections. Just as a responsibility-sharing system was created for employers, the company also assigned each department separate responsibilities. The company also created separate departments to manage the financial operations and the company's vast human resources. Department were also created to curtail waste and to enforce efficient operation. (Xie, 2011, pp. 234-244) The new structure greatly reduced previous redundancies and made for more efficient subway operation. (Xie, 2011, pp. 226-227)

The National Railway Military also turned over the system's operation to a company of its own, behaving more like a regular market corporation. Most of the staff maintained their roles in the subway system, but the company's shift from a governmental military organization to an enterprise paralleled China's shift to a more market-based society after the Cultural Revolution. In 1976, the subway operational division was removed from the Railway Military and was placed under the control of Beijing's transportation department. (Xie, 2011, pp. 167) The company's structure, unlike during the Cultural Revolution, no longer featured politically-related units.

\footnotetext{
${ }^{4}$ Line 1 referred to here is the combination of the western part (west of Nanlishilu) of Phase I of the project and the later constructed part that ran service to Bawangfen (now Sihui East). The eastern part of Phase I (east of Nanlishilu) were combined with Phase II of the project to from the current inner loop line, line 2
} 
(Xie, 2011, pp. 172) In 1984, the company gained independence from Beijing's transportation department, although it remained $100 \%$ nationally owned. (Xie, 2011, pp. 246) This independence, stipulated under the Beijing City Council's agreement, signifies that the city recognized the importance of the subway system in its urban transit network, disconnected from governmental ideology. Additionally, the burden of operation costs and new construction meant that the subway system would function more smoothly if it was to administer itself and control its own budget. In 1985, the company successfully negotiated with the city for extra funding to cover its operation costs, a further indicator that the system served now as a public transportation method instead of political tool. (Xie, 2011, pp. 249) The city renegotiated the company's financial grants in 1988, and instead of linking the funding to ridership as did the 1985 plan, the new agreement would see the company receiving grants only if certain criteria, including on-time rates and accident numbers, were met. (Xie, 2011, pp. 258) If the company did not meet agreed-upon standards, the grant would be reduced, or even withheld. Despite the company still being nationally owned, this gesture indicated the Chinese government's intention to further the free-market economy. New HR and performance-related wage regulations were also put in place in the last decade of the $20^{\text {th }}$ century. (Xie, 2011, pp. 324-340)

The subway system began further construction and expansion as well, even utilizing modern, capitalist economic means to gain funding. Construction on the second phase of the original plan began in 1971 and was completed in 1984. The second phase, along with the southern section of the first phase, would eventually link up to become today's Line 2, which officially passed quality test in 1989. (Xie, 2011, pp. 221) The original Line 1, which terminated at Fuxingmen, was to be extended through the core of the city under the Chang'an Avenue to the then-named Bawangfen station. ${ }^{5}$

However, when construction was about to begin in late 1992, the company could not secure enough funding. (Xie, 2011, pp. 354) The city had to borrow funds from Japan and England to start construction and update the existing signal systems. The borrowed money, however, was not enough to cover the cost of construction. The national economic boom in 1994 caused the prices of steel, concrete and other essential construction materials to rise; thus the funding dried up quickly, before even half of the construction was complete. (Xie, 2011, pp. 356) The subway operation company had to issue bonds to gather further funding. The bonds had little use in helping the construction, but this is another example of the market approach that the government was willing to take amidst economic development. (Xie, 2011, pp. 356) The construction was halted in 1995 due to rising costs, but was restarted during the Asian Economic Crisis in 1997, as a means to use infrastructural construction to reinvigorate the economy. (Xie, 2011, pp. 356)

\section{2001-Present: "Game On"}

With the ever-growing development of China and its economy in the new millennium, the subway system entered a rapid phase of development. In 2001, The International Olympics Committee announced Beijing as the host city for the $28^{\text {th }}$ summer Olympics, which served as another catalyst for system-wide changes. Between 2001 and 2018, the system's average daily ridership rose from 1.3 million to 10 million. In this latest phase of development, the subway system experienced explosive construction, company restructuring, technological updates and innovative ways of financing the company, including the introduction of Public Private Partnership. The practices of the subway company reveal further capitalist politics and diversity of economic measures.

After the success of the city's Olympics bid in 2001, Beijing jump-started a massive wave of subway construction in order to improve the city's transportation, as well as using the subway to advertise China as a technologically advanced, modern nation. The Olympic Park even received its own subway station; city officials decided to construct 4 stations of the planned Line 8 in advance of the games to offer better connection for Olympics spectators. Plans were made in 2001 to construct 8 different lines and add 154.5 kilometer of tracks before 2008 for the Olympic games. Not all lines were finished in time, but the central Olympic stadiums, including the Bird's Nest and Water Cube, were well-connected. (Xie, 2011, pp. 397) Beijing also constructed an Airport Express line connecting the Capital International Airport to the subway system. The Airport Express was constructed with a higher speed limit, special car configuration, and contains only two stops, all measured to ensure a feeling of travel in "business-class."

During this phase of development, the planners also designed suburban subways, which, have the same average station distance and same speed as regular subway trains in Beijing. These lines were not effective solutions as traveling from stations further away from city center sometimes takes longer than bus journeys traveling the same distance. On one hand, the failure to construct lines with longer station intervals at higher speeds reveals

\footnotetext{
${ }^{5}$ Currently the terminal of Line 1, named Sihui East
} 
the Chinese planners' lack of experience, but on the other hand, the suburban lines showcase the city's successful development of surrounding areas in response to massive transportation demands.

All of the lines constructed in this phase, and in the foreseeable future, come with a higher design standard that included more modern decoration and functionality. Stations are designed with screen doors for every platform, elevators and escalators are included for accessibility, and automatic fire extinguishing systems were installed as well. Instead of decorating with ceramic tiles depicting Chinese stories, which had started to fall apart due to maintenance difficulties, the new stations featured LED lights, glass, modern and colorful mosaics and plastic decorations. Each station usually has a central color and a theme to reflect the culture of its neighborhoods. The walls of the Olympic Park stations have illustrations of sports, the Nanluoguxiang station in the heart of Beijing's Hutongs received decorating boxes that held Beijing folklore, and the Military Museum station used traditional Chinese chess as a decoration theme. The system also redesigned the its signage, and newer lines feature LED signage that's constantly up-to-date. These design principles, first employed in the subway lines for the Olympics, are still being used today. Owning in part to this development boom, the system in 2017 operates over 600 kilometer of tracks, 370 stations, and transports 3.78 billion people each year, effectively making it one of the world's largest subway system. (Beijing Municipal Bureau of Statistics, 2017, http://www.bjstats.gov.cn/zxfb/201702/t20170224_369411.html.)

In preparation for the Olympics, the subway system updated its older components and equipment. The city switched to Automatic Fare Collection (AFC) systems, updated and reinstalled modern train controls to improve efficiency, and even reconstructed older platforms fit in elevators and to provide space for 6-car trains. New cars were purchased that included air-conditioning as well. New security cameras and automatic maintenance equipment were installed, and the company managed to construct an operation center in which all operations from all lines can be monitored live, greatly improving efficiency and decreasing cost. (Xie, 2011, pp. 441-446)

The company managed to further modernize its structure to appear more fitting to the seemingly democratizing economy of China. 13 days after the result of the Olympic bid was announced, what used to be the Beijing Subway Corporation was separated into three companies: the Beijing Subway Group Ltd. that manages finance and planning, the Beijing Subway Construction Management Ltd. that manages construction, and the Beijing Subway Operations Ltd. that was in charge of day-to-day operation. (Xie, 2011, pp. 399) Despite still being fully nationally owned, the company successfully restructured itself to resemble companies that participate in market economy, demonstrating a broader trend in the Chinese economy. (Xie, 2011, pp. 401) The company-wide restructuring resulted in reduction of personnel, optimized operation protocols, improved efficiency due to new driver shift arrangements, and separated operation department and staff logistics department. Also worthy of note, the subway police, the company's own police force and a product of Maoist era commands, was handed over to the Beijing police department. The aforementioned Political Defense Crew and Reception Crew also faded out of the company structure, signaling a complete reform from serving political goals to serving the public's transportation needs. (Xie, 2011, pp. 412-420)

In an effort to reduce public spending, the government also decided also to utilize the Public-Private Partnership, or PPP, in constructing its subway systems. The subway Line 4 carried a 15.3 Billion Yuan construction fee and was paid through a combined effort between the government and the private sector. The Hongkong MTR company won the rights to operate the line for 30 years with an investment of 735 million Yuan. (People's Daily, 2005, http://en.people.cn/200604/15/eng20060415_258614.html) These efforts, which the company replicated for Line 14 and 16 as well, further shows China's attempt to marketize its economy.

\section{Conclusion}

The construction of the Beijing subway system offers a valuable reflection of China's political and economic development during and after the Cultural Revolution. The system's purpose shifted from serving national interest to efficiently transporting passengers. The Olympics also played a major role in helping the system transform from an outdated and inconvenient method of transport to a modern and efficient mode of travel within the city. Beijing is also learning from its former inefficiency, constructing more rapid lines to fill demand and responding to citizens' travel requests as China's standard of living rises rapidly. However, despite massive public infrastructure spending by the Chinese government as a means to stimulate the economy, the government has recently decided to roll back on subway spending, perhaps in fear of upcoming economic instability owning to the trade war with US and more. (L. Sun, 2018)

\section{References}

Beijing Municipal Bureau of Statistics. (2017, February 25). Beijingshi 2016nian Guominjingji he Shehuifazhan Tongji Gongbao [2016 Statistics Report of Beijing's Economic and Social Development]. Retrieved October 
31, 2018, from http://www.bjstats.gov.cn/zxfb/201702/t20170224_369411.html

Chang, X. (Ed.). (2007, January 22). Bo Yibo Tongzhi Shengping [Life of Comrade Bo Yibo]. Retrieved August 4, 2018, from http://cpc.people.com.cn/BIG5/64093/64387/5309618.html

Farley, R. (2017, September 6). China vs. america: Why the korean war was total hell (And it's not over). Retrieved September 9, 2018, from https://nationalinterest.org/blog/the-buzz/china-vs-america-why-the-korean-war-was-total-hell-its-not-2219 6

Garver, J. W. (n.d.). China's decision for war with india in 1962. Retrieved September 9, 2018, from http://indianstrategicknowledgeonline.com/web/china\%20decision\%20for\%201962\%20war\%202003.pdf

Hong kong MTR corp wins 30-year operation of new beijing metro line. (2005, April 15). Retrieved August 31, 2018, from People's Daily website: http://en.people.cn/200604/15/eng20060415_258614.html

Kissinger, H. (2012). On China. New York, NY: Penguin Books.

Li Fuchun Jianli [Resume of Li Fuchun]. (n.d.). Retrieved August 4, 2018, from http://www.gerenjianli.com/Mingren/03/rtr9de1rle561rl.html

Lieberthal, K. G. (n.d.). Cultural revolution. Retrieved August 4, 2018, from https://www.britannica.com/event/Cultural-Revolution

Millett, A. R. (2018, June 18). Korean war. Retrieved August 4, 2018, from https://www.britannica.com/event/Korean-War

Sun, D., \& Xu, H. (2013). Beijing jiaotongshi: Beijing zhuanshi jicheng (G. Wang, Comp.). Beijing, China: Renmin Chubanshe.

Sun, L. (2018, July 30). Guidao Jiaotong Jianguan Fengbao [Wave of supervision over rain-based transportation]. Caixin Weekly, 66-71.

Wearden, G. (2010, August 16). Chinese economic boom has been 30 years in the making. Retrieved August 19, 2018, from https://www.theguardian.com/business/2010/aug/16/chinese-economic-boom

Xie, Z., Xie, Y., \& Zhang, S. Comps. (2011). Beijing ditie fazhanshi. Beijing, China: Beijing Chubanshe.

Xinhua News Agency. (2017, December 30). Beijing: The opening and closing time of three new subway lines has been announced. Retrieved September 9, 2018, from http://www.xinhuanet.com/politics/2017-12/30/c_1122188643.htm

Zhang, H. (Ed.). (n.d.). Luo ruiqing. Retrieved August 4, 2018, from http://cpc.people.com.cn/GB/64162/126778/127855/7537195.html

\section{Copyrights}

Copyright for this article is retained by the author(s), with first publication rights granted to the journal.

This is an open-access article distributed under the terms and conditions of the Creative Commons Attribution license (http://creativecommons.org/licenses/by/4.0/). 